\title{
Heavy metal concentrations in sediments of the Capibaribe River Estuary in the Metropolitan Region of Recife, Pernambuco-Brazil
}

\author{
S. J. Macedo ${ }^{1}$, H. K. Philippini da Silva ${ }^{2}$, F. M. M. Brayner ${ }^{2}$, \\ M. M. M. B. Duarte ${ }^{2}$ \& A. M. F. Barbosa ${ }^{2}$ \\ ${ }^{1}$ Department of Oceanography, Federal University of Pernambuco-Brazil \\ ${ }^{2}$ Institute of Technology, Pernambuco-Brazil
}

\begin{abstract}
The objective of this research was to assess the heavy metal concentration in sediments from the Capibaribe river estuary located in Recife City (Pernambuco, Brazil). Sampling was carried out in the rainy and dry seasons in six fixed stations along the river estuary during the rainy/2002 and dry/2003 seasons. Superficial sediment samples were collected between $0-10 \mathrm{~cm}$ deep, during low tide. 14 traps were also used and the settled sediment collected 24 hours later. Dissolved oxygen, $\mathrm{pH}$, salinity, temperature and water transparency data were obtained in the same stations. To quantify cadmium, cobalt, copper, chromium, iron, lead, manganese, nickel and zinc metals an Atomic Emission Spectrometer with Inductive Coupled Plasma (ICP-AES) method was used. No cobalt, lead or nickel were detected, all of them below the quantifying limit. The obtained results to both sediments and sedimentary material showed concentration levels above "background" indicating a high level of contamination in the study area. The $\mathrm{pH}$, salinity, temperature and water transparency parameters results are as expected to estuarine areas. The dissolved oxygen content indicated that pollution is threatening the water quality in the area studied.
\end{abstract}

Keywords: estuary, heavy metal, sediments.

\section{Introduction}

Estuaries are complex ecosystems that are controlled and regulated by a variety of physicochemical and biological processes. In addition, estuarine organisms 
experience a variety of natural and anthropogenic stressors, both of which vary spatially and temporally. In estuaries, potentially toxic chemicals enter waters dissolved in water or attached to suspended particulate matter. Most waterborne toxic substances are hydrophobic and bond to particulates. As particulates and associated toxicants become increasingly dense, they can sink to the bottom in low-energy areas where they become incorporated into sediments. Therefore, sediments that have accumulated in depositional zones where they are not disturbed by physical processes or other factors can provide a relatively stable record of toxicant inputs $[1,2]$. The fate of most anthropogenic heavy metals is in the sediments $[3,4]$.

The Capibaribe river estuary, located in Recife City receives anthropogenic contamination from a variety of sources. Most wastewaters of Recife City are discharged into this estuary. As a result of these anthropogenic inputs this estuarine area is negatively affected by contaminants and the water is listed as impaired [5]. Despite the environmental degradation of the Capibaribe estuary, the relative contributions of specific contaminant sources to the impairments are usually unknown.

The primary objective of this paper is to provide an overview of the chemical results of the Capibaribe estuary. The information will be useful as a reference database for future stressor source comparations that will be needed for effective regulatory management of this important habitat and will also add to the continuing effort to validate the relevance of current diagnostic procedures used in sediment hazard assessment process.

\section{Studied area}

Recife, capital of the state of Pernambuco, is the third largest city in the Northeastern Region of Brazil. Recife (7'43', $8^{\circ} 19^{\prime} \mathrm{S}$ and $34^{\circ} 54^{\prime}, 36^{\circ} 42^{\prime} \mathrm{W}$ ) is the 5th largest metropolitan area in Brazil and the capital of Pernambuco. Recife is also where the Capibaribe River flow into the Atlantic Ocean. This river estuary extends more than $15 \mathrm{~km}$, mostly within urban areas in the city of Recife, with a high population density and many heavy industries dealing with metal including platting. Thus, the river receives many different forms of pollution such as wastewater, litter or industrial effluents without treatments as well as sediments derived from the degradation of its borders or from hills erosion located around the city [6].

The climate is warm-humid, pseudo-tropical (Köppen As') with a mean annual temperature of $26^{\circ} \mathrm{C}$ and a rainfall of $1500-2000 \mathrm{~mm} \cdot \mathrm{yr}^{-1}$, concentrated from March to August. Humidity is generally higher than $80 \%$. Southeast winds predominate.

Extensive mangrove areas have been destroyed although, distributed along the estuary, are small patches of Rhizophora mangle L., Laguncularia racemosa Gaertn and Avicennia schaueriana Stapf \& Leechman [7].

A study of the sediments of the Capibaribe river estuary shows that sediments of the bed of the river are generally coarse sand derived from the reworking of the alluvium from the banks and bed which are dredged out by tidal currents 
directly from these coastal plain deposits. The Capibaribe river, almost without force during the summer low stage transports only fine sediments, principally clays, which are deposited on the banks. These deposits are in the form of mud clay resulting from the sedimentation of flakes and aggregates during the slak between tides. There is little or no calcium carbonate present in the sediments but there is a great quantity of organic matter and very high of organic carbon, which to the $\mathrm{C} / \mathrm{N}$ ratio very high values [8].

The mineralogical analysis of sediment samples collected along the Capibaribe estuary reveals the presence of kaolinite, ilite and feldspar group as well as quartz and hematite [5].

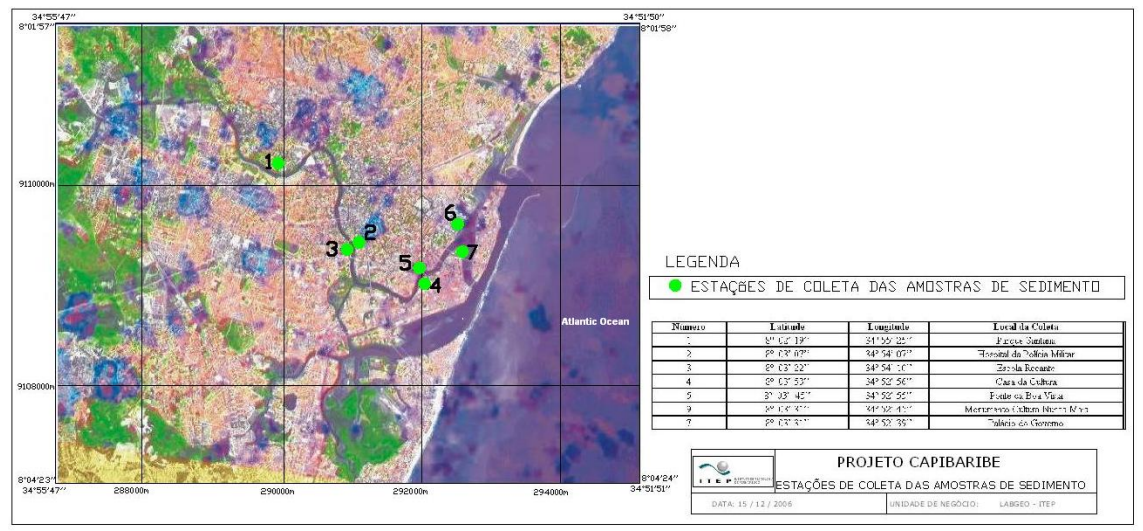

Figure 1: $\quad$ Sampling sites in the Capibaribe estuary, Recife (PE).

\section{Materials and methods}

\subsection{Sampling}

Six fixed stations were positioned using a GPS (Global Position System) and distributed along the right and left borders of the estuarine area and numbered from 02 to 07. Samples collections were performed during the rainy (July August/2002) and dry (January - February/2003) Seasons. Station 01 was used as reference and for this reason was far from the other stations. However, this station showed a high concentration of heavy metal, thus becoming another monitoring point.

\subsubsection{Hydrology}

Physical and chemical data were collected at surface water to determine the main estuarine circulation. A Kitahara/Nansen bottle adapted with a reversing thermometer was used. Samples to determine dissolved oxygen were fixed "in situ" and analyzed in laboratory according to modified Winkler method [9].

Water transparency was measured using a Secchi Disc. A reversing thermometer was used to measure water temperature, submersing it for five 
minutes in the water column; salinity (Morh - Knudsen method); $\mathrm{pH}$ potentiometric method and oxygen saturation rate by the International Oceanographic Tables.

\subsubsection{Sediment}

Superficial sediment samples were collected on the border of the Capibaribe estuary at $0-10 \mathrm{~cm}$ deep during low tide. Fourteen traps were used to collect the sedimentary material (two traps at each station) made of 1 litre polyethylene bottles, which were filled with deionized water and put in a vertical position for 24 hours. After this time, during low tide the bottles were collected and sent to the laboratory.

Sediment samples were dried at ambient temperature, crushed and sieved. After this, all samples were dried at $105^{\circ} \mathrm{C}$ during 24 hours and then burned at $500^{\circ} \mathrm{C}$ to determine organic matter content. The samples collected in traps were filtered and the material dried at $105^{\circ} \mathrm{C}$. The preparation of all samples was made with lithium metaborate fusion in a platinum crucible at $950^{\circ} \mathrm{C}$. The total metal concentrations were determined by means of an Atomic Emission Spectrometry with Inductive Coupled Plasma (ICP-AES).

\section{Results}

\subsection{Hydrological parameters}

The minimum recorded for water transparence index was $20 \mathrm{~cm}$ at station 4 in July/2002 and the maximum was $80 \mathrm{~cm}$ at the same station 4 in August/2002 and January/2003. The minimum recorded temperature was $25^{\circ} \mathrm{C}$ at station 4 in July/2002 and the maximum temperature was $32^{\circ} \mathrm{C}$ at stations 2 and 3. During the study months water salinity presented a maximum value of $10.7 \%$ at station 4 in August/2002 and a minimum value of $0.1 \%$ at station 1 in August/2002. During the study period, the oxygen dissolved in water in the estuary showed great variations, from minimal, undetectable values recorded at station 4 in July/2002 to a maximum of $4.70 \mathrm{ml.} \mathrm{l}^{-1}$ which occurred in January/2003 at station 1. The dissolved oxygen saturation rate during the study months proved to be quite variable, oscillating from the minimal undetectable rate in July/2002 to the maximum rate of $92.34 \%$ recorded in February/2003 at station 4 and January at station 1 of the superficial water column layer. The minimum value obtained was 7.0 at station 2 in January/2003 and the maximum recorded was 8.07 in July/2002 (Figure 2).

\subsection{Organic matter}

Organic matter content ranged from $12.93 \%$ in August $/ 2002$, at station 2 to $19.54 \%$ at station 5 in January $/ 2003$. The organic matter content in the traps ranged with minimum values of $17.31 \%$ in August $/ 2002$, in station 7 and a maximum of $37.32 \%$ at station, also in August/2002 (Figure 3). 
Water Transparence

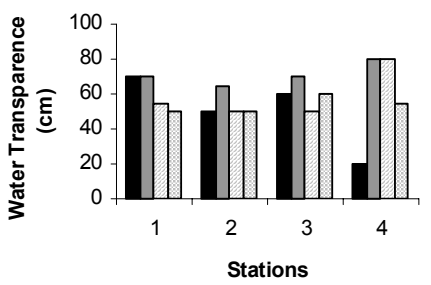

July/2002 $\square$ August/2002

$\square$ January/2003 $\square$ February/2003

Salinity

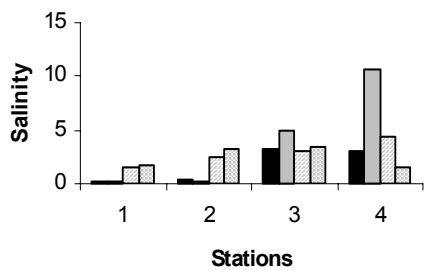

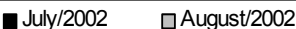

$\square$ January/2003 $\square$ February/2003

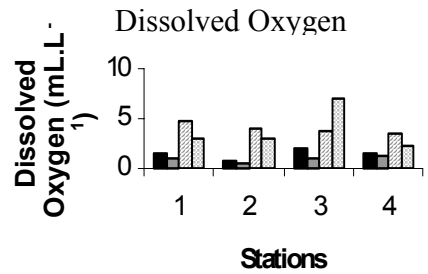

$$
\begin{array}{|ll|}
\hline \text { July/2002 } & \square \text { August/2002 } \\
\square \text { January/2003 } & \text { 口 February/2003 }
\end{array}
$$

Temperature

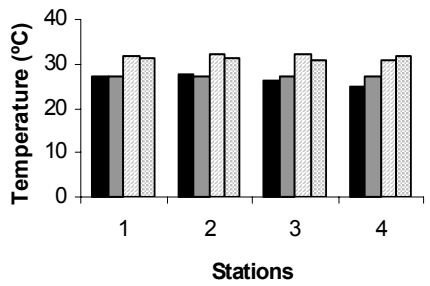

Duly/2002 口August/2002

$\square$ January/2003 $\square$ February/2003

Hydrogenionic Potencial - pF
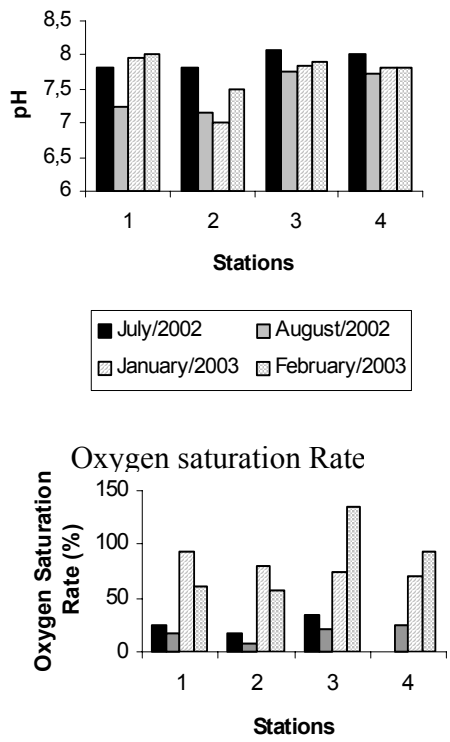

July/2002 口August/2002 $\square$ January/2003 $\square$ February/2003

Figure 2: $\quad$ Temperature, salinity, $\mathrm{pH}$, dissolved oxygen and oxygen saturation rate during the rainy and dry seasons.

\subsection{Heavy metals}

The determination of nine elements $(\mathrm{Cd}, \mathrm{Co}, \mathrm{Cr}, \mathrm{Cu}, \mathrm{Fe}, \mathrm{Mn}, \mathrm{Ni}, \mathrm{Pb}$ and $\mathrm{Zn}$ ) in sediments and sedimentary material was the initial proposition of this study but $\mathrm{Co}, \mathrm{Ni}$ and $\mathrm{Pb}$ were not determined because their content was smaller then the method's detection and quantification limits. 


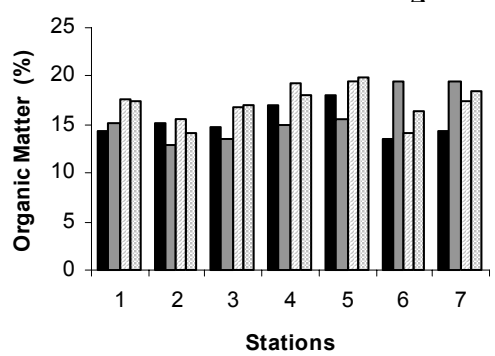

- July/2002 $\square$ August/2002

$\square$ January/2003 $\square$ February/2003

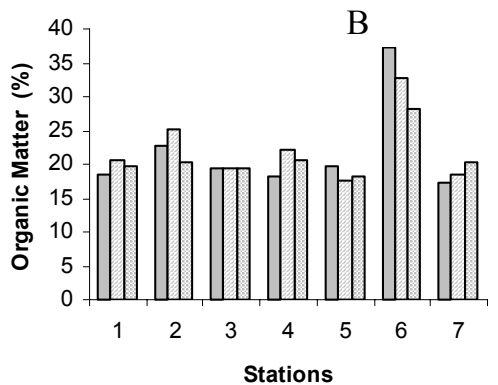

$\square$ August/2002 $\square$ January/2003 $\square$ February/2003

Figure 3: Organic matter in the superficial sediments (A) and sedimentary material (B) during the rainy and dry seasons.

The concentrations of chromium in the study area's superficial sediment oscillated between $76 \mathrm{mg} . \mathrm{kg}^{-1}$ in July/2002 at station 6 and $247 \mathrm{mg} . \mathrm{kg}^{-1}$ at station 7 in February/2003 In the sediment material, the chromium concentration varied from $87 \mathrm{mg} \cdot \mathrm{kg}^{-1}$ in August $/ 2002$ at station 5 to $157 \mathrm{mg} \cdot \mathrm{kg}^{-1}$ at station 6 in February/2003

The concentrations of manganese in the superficial sediment oscillated between $173 \mathrm{mg} \cdot \mathrm{kg}^{-1}$ in January/2003 at station 4 and $465 \mathrm{mg} \cdot \mathrm{kg}^{-1}$ at station 2 in July/2002, The sediment showed concentrations of manganese varied between $154 \mathrm{mg} \cdot \mathrm{kg}^{-1}$ in August $/ 2002$ at station 6 and $391 \mathrm{mg} \cdot \mathrm{kg}^{-1}$ at station 3 in January2003. Iron concentrations in the sediment varied from $31.080 \mathrm{mg} \cdot \mathrm{kg}^{-1}$ in July/2002 at station 6 and $52.013 \mathrm{mg} \cdot \mathrm{kg}^{-1}$ at station 2 in July/2002 In the sediment, iron concentrations varied from $36.053 \mathrm{mg} \cdot \mathrm{kg}^{-1}$ in August/2002 at station 6 to $48.880 \mathrm{mg} \cdot \mathrm{kg}^{-1}$ at station 3 in August/2002. Copper concentrations in the superficial sediment varied between $21 \mathrm{mg} . \mathrm{kg}^{-}$in July/2002 at station 5 and $146 \mathrm{mg} . \mathrm{kg}^{-1}$ at station 2 in February/2003. In the sediment, copper concentrations varied from $12 \mathrm{mg} \cdot \mathrm{kg}^{-1}$ in January/2003 at station 3 to $136 \mathrm{mg} \cdot \mathrm{kg}^{-1}$ at station 6 in August/2002. Zinc concentrations in superficial sediment oscillated between $144 \mathrm{mg} \cdot \mathrm{kg}^{-1}$ in July/2002 at station 2 and $406 \mathrm{mg} \cdot \mathrm{kg}^{-1}$ at station 6 in August/2002. In the sediment material these concentrations vary from 191 mg. $\mathrm{kg}^{-1}$ in August/2002 at station 5 to $655 \mathrm{mg} \cdot \mathrm{kg}^{-1}$ at station 6 in February/2003.

\section{Discussion}

The magnitude from seasonal variations of hydrologic parameters is mostly very different, when compared with coastal oceanic regions. The quantity of fresh water that enters the estuaries is very important, considering it enriches the estuary with nutrients but, also carries a great quantity of pollutants discharged from urban and industrial effluents. 
In the Capibaribe estuarine zone water transparency was relatively low, showing little variation among collection stations and during the rainy and dry periods. Lower values were found at the collection station near the mouth of the estuary which is influenced by ocean water.

Seasonal temperature variations became characterized by progressive increases during the dry period. The variations in the registered thermal index $\left(4.5^{\circ} \mathrm{C}\right)$ were lower and this is characteristic of tropical estuarine regions.

The estuarine regions showed considerable fluctuations in salinity due to the fresh and saline water mix being usually less than the adjacent sea. The studied area showed considerable fluctuations in salinity, changing from limnetic values (salinity lower than $0.5 \%$ ) to mesoaline values (maximum of $10.7 \%$ ) during low tide. The seasonal variation was quite evident considering the highest values were recorded during the dry season and lowest values in the rainy season.

The dissolved oxygen value is a basic element to determine water quality; the results of dissolved oxygen demarcated polluted or non-polluted areas, with oxygen saturation rates reaching values smaller than the method's detection limit or near this value. One may emphasize that these lower values threaten the fauna, flora and certain physical or chemical mechanisms of many ions present in the water ambient. Despite lower dissolved oxygen contents being detected the value obtained for $\mathrm{pH}$ were alkaline, showing regular water acid/basic mechanisms conditioned by tide currents that cause a quick recycling of chemical and biological resources in the ecosystems. The natural organic matter in mangrove areas plays an important role in the water ambient metal cycles. Most particulate and dissolved organic matter present in aquatic ecosystems is derived from plants (macro algae and phytoplankton) and microorganisms (bacteria, fungi and viruses). The organic matter results from sediments and sedimentary material for 24 hours, didn't show significant differences except in the trap from station number 6 , which showed double what was obtained at other stations during the studied period, indicating the environment in that point became more polluted because the tide cycle anthropic actions, and a large organic load.

To evaluate the degree of contamination or the increase in metal contribution to the environment Carral et al [10] describe that it is necessary to determine, the levels of natural metals (background concentrations) in the studied environment to evaluate the impact of anthropic actions. In this study, the results obtained by Brayner et al [5] in the analysis of samples collected in a preserved mangrove area, and the same characteristics being found in studied sediments, was used as background.

In February, due to the strong rainfall during the collection period that modified the estuary characteristics atypical values were detected for studied metals.

When comparing the chromium results obtained in this study with that of proposed background, it was observed that chromium contents in sediment and sedimentary material from the Capibaribe river were higher than the background showing pollution at all collection stations. 
In the Capibaribe estuary, during February/2003, there was a significant amount of Chromium in superficial sediments showing high concentrations in areas without mangrove vegetation like at collection stations 5 and 7.

The results obtained for iron and manganese in this study, showed that sediments are affected because of the different industrial and urban activities developed in the region as well as the chemical properties of these elements with little changes in $\mathrm{pH}$, redox potential, dissolved oxygen and salinity contributes to its availability in the environment. The area where there was mangrove vegetation showed lower values for iron in sediments as much as in sedimentary material. Some manganese results were lower than background values, however the majority of results obtained from sediment as well as from sedimentary material were higher than that of background. At some collection stations during the rainy and dry periods, the highest results for iron and manganese were associated with lower values of dissolved oxygen obtained in sediments and sedimentary material. The anoxic conditions at these collection stations allow modifications in the oxidation number for iron and manganese when in contact with the water column. In this study the results obtained for copper showed higher values than expected in sedimentary material during January/2003 at station number 7 . These higher copper results can be explained by the existence of galvanoplastic industries located near the Capibaribe river estuary.

Station number 6 is the most critical of all other stations with the highest concentration of copper because that is where all modifications that make the estuary environment favorable to metal concentration occur. At station number 1 the fact that the sediments ware stirred up on the collection day may have made the metal more available in the superficial sediments.

Zinc and Cadmium have specific characteristics of their metal groups, such as the exchange forms that make them available in the environment. The highest values of zinc were associated with more rainfall which modified the chemical composition of water during the collection period.

Thus, the seasonal conditions were the main fact related with metal distribution in sediment and sedimentary material in the Capibaribe river estuary. Significant differences were also observed among the collection stations when comparing results obtained from sediment and sedimentary material over the 24 hours.

\section{Conclusions}

The studies showed that the urbanization of Recife City has brought negative impacts to the estuarine ecosystem. The results obtained showed that seasonal conditions exerted influence over the hydrological parameters and metal distribution in superficial sediments and sedimentary material over 24 hours. The heavy metal content in superficial sediments and sedimentary material showed contamination by chromium, iron, manganese and zinc since these elements presented concentration levels higher than the background, and indicated there can be a transfer of metal along the estuary considering that metal concentrations were higher in sedimentary material in 24 hours than in superficial sediments. 


\section{References}

[1] French, P.W., Coastal and estuarine management. (Routledge environmental management). New Fetter Lane, London: Routledge, 1997. $251 \mathrm{p}$.

[2] Salomons, W. \& Förstner, V., Metals in hydrocycle. Berlim: Spring Verlag, 1984, 349 p.

[3] Abu - Hilal, A., Observation on heavy metal geochemical association in marine sediments of the Jordan Gulf of Afaba. Marine Pollution Bulletin, 26(2), pp.85-90, 1993.

[4] Williams, T.P., Bubb, J.M. \& Lester, J.N., Metal accumulation Salt Marsh Environments: a review. Marine Pollution Bulletin, 28(5), pp. 277-290, 1994.

[5] Brayner, F.M.M, Silva. H.K.P. \& Barbosa, A.M.F., Behavior of heavy metals in the estuarine area of the Capibaribe River in the Northeast of Brazil. Journal de Physique IV. France 107. pp. 221-225, 2003.

[6] Companhia Pernambucana de Meio Ambiente. Bacias hidrográficas. Online. www.cprh.pe.gov.br.

[7] Coelho, P.A. \& Torres. F.A., Areas estuarinas de Pernambuco. Trabalhos Oceanográficos da UFPE, 17, pp. 4-91, 1982.

[8] Ottmann, F. \& Ottmann, J.M., Les Sediments de L'Embouchure Du Capibaribe, Recife-Bresil. Trabalhos do Instituto de Biologia Marítima e Oceanografia Universidade do Recife, 1(1), pp.51-69, 1959.

[9] Strickland, J.D.H. \& Parsons, T.R., A manual of sea water analysis. Bulletin Fisheries Research Board of Canada. 125, pp. 1-125, 1972.

[10] Carral, et al., Influence of watershed lithology on heavy metal levels in estuarine sediments and organisms in Galicia (North-West Spain). Marine Pollution Bulletin, 30(9), pp. 604-608, 1995. 